\title{
Prevalence and Drug Consumption Habits at the 2011 Peninsula Festival in Tîrgu Mureș
}

\author{
Domokos L1,2, Ábrám Z33, Sebesi Sz², Finta Hajnal4 \\ 1 Psychiatry Clinic II, University of Medicine and Pharmacy, Tîrgu Mureș, Romania \\ 2 PhD student, University of Medicine and Pharmacy, Tîrgu Mureș, Romania \\ 3 Department of Hygiene, University of Medicine and Pharmacy, Tîrgu Mureș, Romania \\ ${ }^{4}$ Gedeon Richter România SA, Tîrgu Mureș, Romania
}

\begin{abstract}
Introduction: In 2010 Romania was ranked fourth in the European Union regarding the prevalence of ethnobotanical drug use with psychotropic effect. The main purpose of our survey was to collect data on substance use and assess drug consumption habits among participants at the 2011 Peninsula Music Festival in Tîrgu Mureș, Romania.

Material and method: The study was carried out as a cross-sectional survey in a sample of 256 persons, using an anonymous, self-administered structured questionnaire, containing questions about the consumption patterns of illegal psychoactive drugs, as well as sociodemographic data which could influence drug consumption (age, gender, educational level, marital status of parents).

Results: Ethnobotanical drug consumption had the highest lifetime prevalence (37.7\%), the second most often used drug was cannabis (marijuana) with a lifetime prevalence of $35.2 \%$. Males and females differed significantly in the use of marijuana $(p=0.023)$ and ethnobotanical drugs ( $p=0.008$ ) in the last 12 months, male respondents used more of these psychoactive substances. In the case of children with divorced parents the last 12 months marijuana use $(p=0.032)$ and ethnobotanical drug use $(p=0.013)$ was significantly higher than in the case of children whose parents were not divorced.

Conclusions: The survey results show the importance of the development of health education programs and drug-prevention strategies for vulnerable goups (festival visitors, minors, children with divorced parents).
\end{abstract}

Keywords: ethnobotanical, marijuana, drug, spice

Received: 15 April 2011

\section{Introduction}

In 2010 Romania was ranked fourth in the European Union, according to the European Commission, regarding the prevalence of ethnobotanical drug use with psychotropic effect - the first was England with 37\%, the second Germany with $15 \%$, then the Netherlands with $14 \%$, and Romania with $7 \%$ [1].

"Ethnobotanical", a noun more recently derived from "ethnobotany", although lexically related to the former, has acquired a significantly narrower meaning: it refers to herbal products used (currently or in the past) by certain world populations in shamanic or religious rituals, and more generally to induce states of alteration of consciousness and the mind (i.e. herbals with narcotic, psychotropic, psychedelic, "entheogen", hallucinogen or psychomimetic properties: Salvia divinorum, Mitragyna speciosa, Amanita muscaria, Psilocybe). Spicing of herbal products is common practice in the marketing of legal highs: a dried and ground herbal product is "spiked" with psychoactive synthetic substances, (Ketamine, Piperazine derivatives, Mephedrone) which are not on the list of controlled substances [2]. In this paper we will use the term "ethnobotanicals" limited to this (rather artificial) sense of herbals with mindaltering properties [3].
According to a report of the General Inspectorate of Romanian Police, at the beginning of the year 2009 there were 18 shops in Romania selling such products. The number of these shops increased rapidly, as in that year the marketing of ethnobotanical drugs was legal. At the end of August 2009, 121 shops were already in existence. In 2010 there were 400 shops marketing such products and over 500.000 consumers in Romania. This phenomenon was considered to be "an explosion" [1,4]. Although few of these were on-line shops (or at least selling also through the internet), most of them were functioning only in the conventional way.

The use of products sold through these commercial channels was far from safe. Based on the data gathered by the Romanian Ministry of Health, in 2009 more than 1300 persons, mostly young people asked for medical help, being seriously poisoned by ethnobotanical drugs [4]. A considerable proportion of these persons were children: in Iași county, 10 out of the 66 cases who needed hospital care were minors [3]. These products were traded in the form of cigarettes, tablets, powders, vegetable fragments packed in sachets, under various names, the sales price varying according to weight.

Based on the data of international comparative examinations (ESPAD), in 2007 the drug use indicators among Romanian young people were lower than the European average [5]. 
The main purpose of our study was to collect data on substance use and assess drug consumption habits among participants at the 2011 Peninsula Music Festival, Tîrgu Mureș, Romania.

\section{Material and method}

The study was carried out as a cross-sectional survey. We used a random sampling method, the sample included 256 persons. We gathered data using an anonymous, self-administered, structured questionnaire, based predominantly on closed questions about the consumption patterns of illegal psychoactive drugs, as well as sociodemographic data which could influence drug consumption (age, gender, educational level, marital status of parents).

Data were analyzed using the statistical software SPSS version 15.0, and various statistical methods: Shapiro Wilk test (for testing the normal distribution of the sample), Fisher's exact test (for testing the null hypothesis: there is no significant association between drug consumption and socio-demographic background). Rejection of the null hypothesis was based on the following levels of significance: $\mathrm{p}$ value $=0.05(<0.05$ : significant, $<0.01$ : highly significant).

\section{Results}

The gender and age distribution of the sample can be seen in Figure 1. Gender distribution: $59.37 \%$ male and 40.63 $\%$ female. Age distribution: mean age 21.60 years, median 21 years, standard deviation 4.33 years, minimum 15 years, maximum 33 years. Shapiro Wilk test: non-parametric distribution ( $\mathrm{W}=0.925, \mathrm{p}=0.000)$.

Thirty-seven point seven percent of the people questioned used ethnobotanical drugs during their lifetime and $19.8 \%$ used them during the last 12 months (Figure 2). The second most often used drug was cannabis (marijuana): $35.2 \%$ of the people questioned used cannabis during their lifetime and $20.6 \%$ of them used this drug during the last 12 months. The third most often used psychoactive substance was anxiolytic medication (not prescribed by a physician): $8.6 \%$ of the people questioned used anxiolytics during their lifetime and $4.8 \%$ of them used these drugs during the last 12 months. The fourth most often used

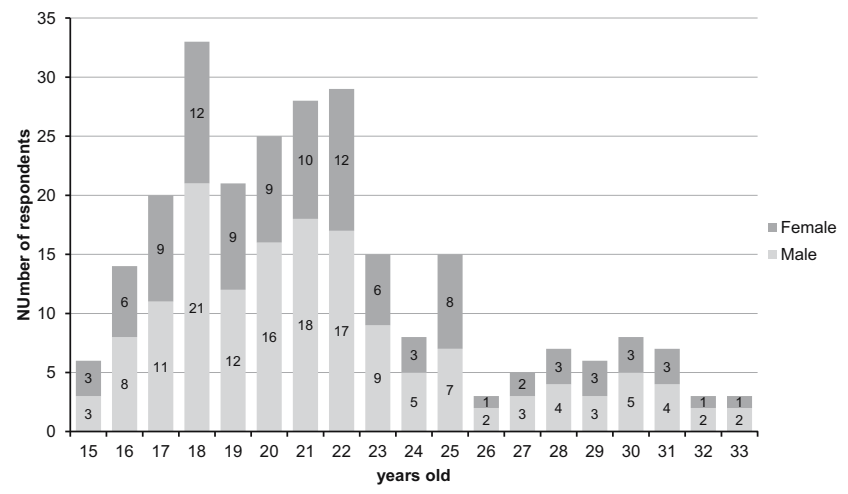

Fig. 1. Gender and age distribution of the respondents substance was amphetamine and methamphetamine derivatives (speed and ecstasy): $4.8 \%$ of the people used speed and ecstasy during their lifetime and $3.6 \%$ of people used amphetamines during the last 12 months. The fifth was heroin: $2.4 \%$ of the people questioned used heroin during their lifetime and $1.2 \%$ of them used this drug during the last 12 months. The substance with the lowest usage was cocaine: $1.8 \%$ of the people questioned used cocaine during their lifetime and $1.2 \%$ of these people used this drug during the last 12 months.

In order to assess whether drug consumption differs in terms of sociodemographic status, we applied Fisher's exact test of association. The results are presented in Table I: males and females differed significantly regarding the use of marijuana $(\mathrm{p}=0.023)$ and ethnobotanical drugs $(\mathrm{p}=$ 0.008 ) in the last 12 months, male respondents using more of these psychoactive substances. Males and females differed significantly in the last 12 months regarding the use of anxiolytics without a physician's presciption ( $\mathrm{p}=0.033)$, here the female respondents predominated. Concerning ecstasy and speed consumption no significant gender difference was found $(\mathrm{p}=1.000)$.

We examined age differences (minor status - respondent $<18$ years and major status - respondent $\geq 18$ years) and illicit psychoactive substance use. Based on the results in Table I, minor and major respondents differed significantly in the last 12 months regarding marijuana use $(\mathrm{p}=$ $0.040)$, speed and ecstasy use $(\mathrm{p}=0.020)$, and anxiolytics use without a physician's prescription $(\mathrm{p}=0.040)$, with a higher prevalence of major consumers and there were no significant differences between minor and major respondents in the last 12 months regarding ethnobotanical drug use $(\mathrm{p}=0.404)$.

We found a significant association between the parents' marital status and drug use of the respondents. In the case of children with divorced parents marijuana $(\mathrm{p}$ $=0.032)$ and ethnobotanical drug use $(p=0.013)$ in the last 12 months was significantly higher than in the case of children whose parents were not divorced. We did not find a significant association between the parent's marital status and ecstasy and speed use in the last 12 months $(\mathrm{p}=$

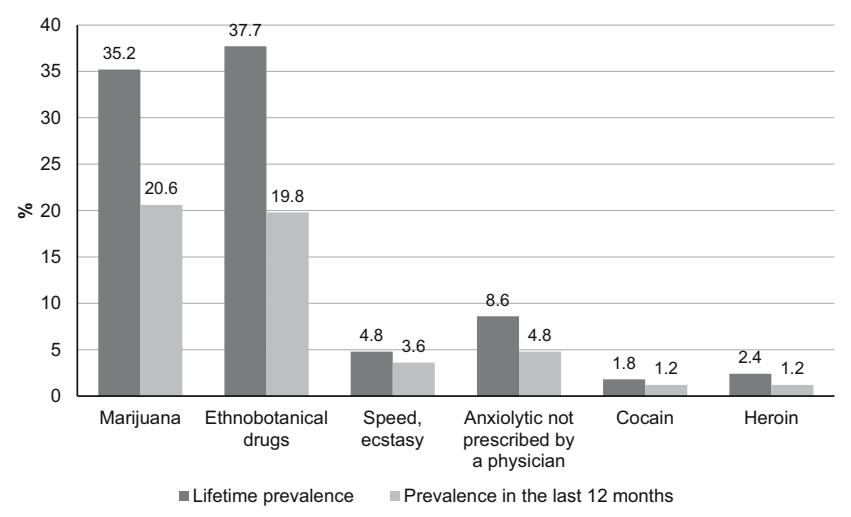

Fig. 2. Drug consumption prevalence at the 2011 Peninsula Festival 
Table I. Associacions between sociodemographic factors and illicit psychoactive substance use in the last 12 months

\begin{tabular}{|c|c|c|c|c|c|c|c|c|c|}
\hline \multirow[t]{2}{*}{ Psychoactive substances } & \multicolumn{3}{|c|}{ Gender } & \multicolumn{3}{|c|}{ Age (minor/major status) } & \multicolumn{3}{|c|}{ Parents' marital status } \\
\hline & $\begin{array}{c}\text { Male } \\
(59.3 \%)\end{array}$ & $\begin{array}{l}\text { Female } \\
(40.6 \%)\end{array}$ & $\mathrm{p}$ & $\begin{array}{c}<18 \text { years } \\
(16.4 \%)\end{array}$ & $\begin{array}{c}>18 \text { years } \\
(83.6 \%)\end{array}$ & $\mathrm{p}$ & $\begin{array}{l}\text { Divorced } \\
(34 \%)\end{array}$ & $\begin{array}{c}\text { Married } \\
(66 \%)\end{array}$ & $\mathrm{p}$ \\
\hline Marijuana & $74.6 \%$ & $25.4 \%$ & 0.023 & $7.4 \%$ & $92.5 \%$ & 0.040 & $47.0 \%$ & $53.0 \%$ & 0.032 \\
\hline Ethnobotanical drug & $80.3 \%$ & $19.7 \%$ & 0.008 & $20.7 \%$ & $79.3 \%$ & 0.404 & $49.0 \%$ & $51.0 \%$ & 0.013 \\
\hline Speed, Ecstasy & $65.2 \%$ & $34.8 \%$ & 1.000 & $5.6 \%$ & $94.4 \%$ & 0.020 & $16.6 \%$ & $83.4 \%$ & 0.138 \\
\hline $\begin{array}{l}\text { Anxiolytics not pre- } \\
\text { scribed by a physician }\end{array}$ & $24 \%$ & $76 \%$ & 0.033 & $7.4 \%$ & $92.6 \%$ & 0.040 & $38.7 \%$ & $61.3 \%$ & 0.502 \\
\hline
\end{tabular}

$0.138)$, and anxiolytics use without a physician's prescription in the last 12 months $(\mathrm{p}=0.502)$.

\section{Discussions}

The most often used drugs among participants at the Peninsula Music Festival were ethnobotanical drugs (37.7\% lifetime prevalence) and marijuana (35.2\% lifetime prevalence). Considering the average population in Romania, the lifetime use for all types of illicit drugs was $4.3 \%$ (including new psychoactive substances) in 2010. Lifetime prevalence rates for cannabis use were $1.6 \%$ in 2010 [6]. The high prevalence of our sample shows that young people attending festivals represent a special population where drug use prevalence highly exceeds that of the average population. Thus, they can be considered a vulnerable group.

While $74.6 \%$ of marijuana and $80.3 \%$ of ethnobotanical drug consumers are male, $76 \%$ of those consuming anxiolytics without a physician's prescription are females. These gender rates and tendencies correspond with the data of the European Monitoring Centre for Drug and Addiction [6].

The statistics show that $7.4 \%$ of marijuana and $20.7 \%$ of ethnobotanical drug consumers are minors and these prevalences are lower compared to Romanian data from 2008 , where $21.7 \%$ of marihuana consumers were minors (in 2008 ethnobotanical substances were not available in Romania) [7]. Although the difference is significant considering the consumption of marijuana, the 2010 ethnobotanical drug use prevalence of minors is almost entirely the same as the 2008 marijuana use prevalence. This shows that minors prefer those drugs that are easily accessible.

Forty-seven per cent of marijuana consumers and 49\% of ethnobotanical drugs are children with divorced parents. These results coincide with other investigations [8], where the relative risk is 2.54 in the case of marijuana users with a single-parent family structure.

\section{Conclusions}

According to our results, the consumption of ethnobotanical drugs and marijuana is higher among male visitors of music festivals. Therefore, the organization of health education programmes at this kind of festivals for this vulnerable group would be very important. The programmes should aim to increase the level of information about drugs, education and awareness of school population (especially in the case of minors), to prevent or delay the onset of drug abuse in schools.

Among young people with divorced parents the consumption of marijuana and ethnobotanical drugs is significantly higher than among those who come from a biparental family. In the case of this group it is recommended to provide help for them to be able to cope with the emotional trauma caused by parental separation.

\section{References}

1. Alexa A. România pe primul loc în UE privind consumul de etnobotanice [Internet]. 2010 [updated 2010 Apr 22]. Available from: http://www. mediafax.ro/social/romania-pe-locul-patru-in-ue-privind-consumul-deetnobotanice-6019315

2. Gorun G, Dermengiu D, Curca G C, Hostiuc S, Ioan B, Luta V. Toxicological drivers issues in "legal highs" use. Romanian Journal of Legal Medicine. 2010;18(4):272.

3. Ancuceanu R, Dinu M, Anghel I, Rebegea O, Olaru T, Popescu D, Popescu G. Recent prohibition of certain psychoactive "ethnobotanicals" in Romania. Farmacia. 2010;58:121-123.

4. Romanian Ministry of Health - Press Service. Ministerul Sănătății a stabilit lista cu plante și substanțe cu proprietăți psihoactive care vor fi interzise, după ce s-au dovedit a fi periculose pentru sănătate [Internet]. 2010 [updated 2010 Feb 10]. Available from: http://www.ms.ro/index. php?pag $=62 \& i d=8095 \& p g=1$

5. Hibell B, Guttormsson U, Ahlström S, Balakireva O, Bjarnason T, Kokkevi A, Kraus L. Substance Use Among Students in 35 European Countries. ESPAD Report. 2007:12

6. European monitoring Centre for Drug and Addiction. National Report Romania. 2011:26

7. Aurora L. Agentia Nationala Antidrog, Prevalenta consumului de droguri în rândul elevilor din învatamântul preuniversitar din judetul Buzau. 2008:126

8. Hemovich V, Crano W. Family Structure and Adolescent Drug Use: An Exploration of Single-Parent Families. National Institutes of Health. 2009;44(14):2099-2113. 